\title{
Microbiological analysis for drug resistant pathogenic microorganisms with determination of the antibacterial properties found in Fragaria $\mathrm{x}$ ananassa (strawberry) samples
}

\author{
Nazneen Piangka, Tasnia Ahmed and Mrityunjoy Acharjee* \\ Department of Microbiology, Stamford University Bangladesh, 51 Siddeswari Road, Dhaka 1217, Bangladesh
}

Received 18 April 2016/Accepted 28 May 2016

\begin{abstract}
Strawberry is a popular fruit item consumed by people all over the world for its exceptional flavor and aroma. This fruit is being used to prepare a wide range of food items. Strawberries when consumed by people without undergoing any processing, the condition may not be good enough. People may get sick after consuming raw strawberries. Our current study identified several pathogenic bacteria which are very known in causing health related problems. $E$. coli was found in one sample $\left(1.0 \times 10^{2} \mathrm{cfu} / \mathrm{g}\right)$, Staphylococcus aureus was commonly present in all of the five samples (up to $1.2 \times 10^{6} \mathrm{cfu} / \mathrm{g}$ ), Klebsiella spp. was found to be present in two samples (within $1.0 \times 10^{3} \mathrm{cfu} / \mathrm{g}$ ) and Pseudomonas spp. was present in three samples $\left(8.2 \times 10^{4} \mathrm{cfu} / \mathrm{g}\right)$, respectively. All isolated bacteria showed some degree of drug resistant traits against some commonly used antibiotics. The most important and promising part of the study was to successfully find the antimicrobial activity of strawberries against seven types of pathogenic bacteria.
\end{abstract}

Key words: Strawberry; Contamination; Drug resistance; Antimicrobial activity

Fruits belong to one of the five major dietary classes of foods for getting proper and healthy nutrition. Fruits not only supply vitamins but also minerals which are essential dietary need for human. Some can cause food borne disease outbreaks if contaminated with pathogenic microbiota (1-4). Many fruits play some other roles in addition to giving us beneficial supplements. They can sometimes antagonize some pathogenic bacteria and fungi by several chemical agents like phenolic compounds, terpenoids, alkaloids etc. produced within them. Strawberry (Fragaria $\mathrm{x}$ ananassa) is a fruit popular for its distinct taste, aroma, color and flavor. Strawberries contain various minerals (iron, calcium, magnesium, phosphorus) and vitamins (K, E, C, A) (5-11). Beyond the beneficial activities, strawberries can also involve in causing disease if harbors adequate levels of pathogenic microorganisms. Microorganisms come in contact with strawberries in the farms through handling, soil quality, fertilizer quality, water quality, equipments used during harvesting, contact with wild life, during transportation and storage procedures (12-14). They also contain phenolic compounds among which allergic acid is produced approximately half of the total phenolics

${ }^{*}$ Corresponding Author: Mailing address. Mrityunjoy Acharjee, Department of Microbiology, Stamford University Bangladesh, 51 Siddeswari Road, Dhaka 1217, Bangladesh, Bangladesh; E-mail: mrityunjoy_111@yahoo.com.
$(15,16)$. It has been proved that the phenolic compounds produced by strawberries can inhibit Escherichia coli, Salomonella spp., Campylobacter spp., Candida spp. etc. (17-22). This is very important to get new therapeutics against these pathogens. Present study has been conducted on five strawberry samples for microbiological investigation as well as detecting antibacterial activity against some common pathogenic bacteria.

\section{MATERIALS AND METHODS}

Study area and sample processing. Five strawberry samples were collected from different super shop markets available in Dhaka city during the time span of January 2016 to February 2016. After aseptical collection of samples, they were transferred immediately to the laboratory for microbial analysis by following the procedures proposed by American Public Health Association. For both microbiological analysis and antimicrobial activity, strawberry samples were processed separately as skin and core. The skin and core separately were homogenized in normal saline followed by serial dilution up to $10^{-6}(23)$

Microbiological analysis. $0.1 \mathrm{ml}$ suspension of strawberry skin suspension and core suspension was introduced onto nutrient agar (NA) and Sabouraud dextrose agar (SDA) media for enumerating total viable bacteria (TVB) and Total Fungal Count (TFC), respectively (24). For identification and enumeration of specific pathogenic bacteria both skin and core suspension was added and spread onto MacConkey agar, mannitol salt agar (MSA) and cetrimide agar media which can detect Escherichia coli, Staphylococcus spp. and Pseudomonas spp., respectively. SDA plates were incubated at $25{ }^{\circ} \mathrm{C}$ for 48 to 72 hours. The other plates were incubated at $37{ }^{\circ} \mathrm{C}$ for 24 hours. Eschericha coli or Klebsiella spp. can be identified by distinguishable pink colony on MacConkey agar, Staphylococcus spp. by their yellow colony on MSA and Pseudomonas spp. by their greenish colored colony on cetrimide agar.

Analysis for the presence of VBNC bacteria. For detection of Salmonella spp. $01 \mathrm{ml}$ homogenized sample of strawberry skin and strawberry core was inoculated into $9 \mathrm{ml}$ selenite cysteine broth (SCB) for enrichment at $37^{\circ} \mathrm{C}$ for 6 hours. For detection of Vibrio spp., both samples from skin and core were inoculated into 9 
$\mathrm{ml}$ alkaline peptone water (APW) by following the same procedure as for Salmonella spp. After enrichment the SCB and APW media containing strawberry samples were serially diluted up to $10^{-6}$. After that samples were inoculated onto Salmonella-Shigella (SS) agar and Thiosulfate Citrate Bile Salt Sucrose (TCBS) agar and incubated at $37{ }^{\circ} \mathrm{C}$ for 24 hours. Black centered colonies on the SS agar is indicative for the presence of Salmonella spp. and the large, yellow colonies on the TCBS agar is indicative for the presence of Vibrio spp. Biochemical tests were performed to ensure the identity of the isolates (25).

Study of antibiotic resistance of the isolates. To determine the antibiotic susceptibility of the detected isolates from the strawberry samples, normal saline was subjected to add fresh isolates to get bacterial suspensions. After appropriate turbidity was attained, these suspensions were inoculated and spread over the Muller- Hinton agar plates using cotton swabs. Then some selected antibiotic discs were placed and incubated at $37{ }^{\circ} \mathrm{C}$ for 24 hours to get the zone of inhibition. Antibiotics used in this study of antibiotic resistance traits, are, Ampicillin $(10 \mu \mathrm{g})$, Amoxicillin $(10 \mu \mathrm{g})$, Nalidixic acid $(30 \mu \mathrm{g})$, Erythromycin $(15 \mu \mathrm{g})$, Chloramphenicol $(10 \mu \mathrm{g})$, Gentamicin $(10 \mu \mathrm{g})$, Kanamycin $(30 \mu \mathrm{g})$, Streptomycin $(10 \mu \mathrm{g})$, Vancomycin $(30 \mu \mathrm{g})$, Ciprofloxacin $(5 \mu \mathrm{g})$, Ceftriaxone

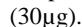

Determination of antibacterial activity of strawberry. To determine the antibacterial activity of the strawberry samples, agar well diffusion method was used. At first some selected bacterial isolate (Pseudomonas spp, Bacillus spp, Salmonella spp, E. coli, Staphylococcus spp., Listeria spp., Klebsiella spp. and Vibrio spp.) were taken to make their suspensions in normal saline. Then the bacterial suspensions were introduced evenly onto Mueller-Hinton agar (MHA) media using cotton swab. Then holes were made using a cork borer on the MHA to introduce strawberry samples in it with a positive (antibiotic disc-Gentamicin

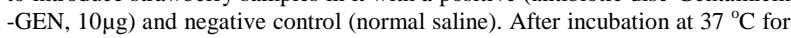
24 hours, plates were observed for the presence of clear zone indicating the antibacterial activity $(26,27)$.

\section{RESULTS AND DISCUSSIONS}

Fruits harbor many different kinds of normal microbiota as well as some pathogenic microbes under several circumstances. While eating raw, we often consume fruits along with such pathogenic and drug resistant microorganisms if not washed properly (28, 29). Different types of infectious diseases can arise from consuming the contaminated fruits. Sometimes they can provide some degree of protection against few pathogenic bacteria (30-32).

During our current study we identified a number of pathogenic bacteria in the strawberry samples (Table 1). Total viable bacterial count was determined between a range of $4.8 \times 10^{5}$ to $2.9 \times 10^{9}$ cfu per gram of sample and total fungal count was found between the range of
$1.3 \times 10^{3}$ to $8.8 \times 10^{5} \mathrm{cfu} / \mathrm{g}$. The indicator bacteria $E$. coli $\left(1.0 \times 10^{2} \mathrm{cfu} / \mathrm{g}\right)$ was found to be present only in one strawberry sample indicating a chance of fecal contamination. The most prominent bacteria in all samples were Staphylococcus aureus ranging from $1.1 \times 10^{3} \mathrm{cfu} / \mathrm{g}$ to $1.2 \times 10^{6} \mathrm{cfu} / \mathrm{g}$. Klebsiella spp. and Pseudomonas spp. were found to be present in two and three samples respectively out of five strawberry samples. The VBNC bacteria Salmonella spp. and Vibrio spp. was totally absent in all samples (Table 1).

After such result we can state that all the strawberry samples harbored Staphylococcus aureus which results from improper and too much handling of them. The bacteria can cause different types of food borne disease both by causing infection and intoxication (29). The environmental condition during transport and storage also encouraged the bacteria to multiply rapidly. E. coli in one sample indicates fecal contamination which can be due to unhygienic handling, using raw and non-treated water during any of the processes from farm to fork (30-32). The total absence of the VBNC bacteria is a good side that health problems associated with VBNC bacteria would not arise in the consumers. So it is really very important to clean fruits with fresh and pure water properly before consumption.

In recent years drug resistance problem has become a burning issue in treating diseases (33). In our study we found the bacterial isolates are resistant to several popular antibiotics (Table 2). Klebsiella spp. is completely resistant against one antibiotic (Imipenem), Pseudomonas spp. against three antibiotics (Ampicillin, Ciprofloxacin and Vancomycin), Staphylococcus spp. against Ampicillin, Kanamycin, Vancomycin. E. coli was still somewhat susceptible to the antibiotics used in this study. Most effective antibiotics for $E$. coli were Streptomycin and Vancomycin (100\%), for Staphylococcus spp. Streptomycin and Gentamycin, for Klebsiella spp. Gentamycin, Imipenem and Ampicillin. Pseudomonas spp. was susceptible (100\%) towards most of the used

TABLE 1. Microbiological analysis of strawberry samples

\begin{tabular}{|c|c|c|c|c|c|c|c|}
\hline & Sample & $\begin{array}{l}\text { TVBC } \\
\text { (cfu/g) }\end{array}$ & $\begin{array}{l}\text { Fungi } \\
\text { (cfu/g) }\end{array}$ & $\begin{array}{l}\text { E. coli } \\
\text { (cfu/g) }\end{array}$ & $\begin{array}{c}\text { Klebsiella } \\
\text { spp. (cfu/g) }\end{array}$ & $\begin{array}{l}\text { Pseudomonas } \\
\text { spp. }(\mathrm{cfu} / \mathrm{g})\end{array}$ & $\begin{array}{c}\text { Staphylococcus } \\
\text { spp. }(\mathrm{cfu} / \mathrm{g})\end{array}$ \\
\hline \multirow[b]{2}{*}{ S1 } & Surface & $1.2 \times 10^{8}$ & $3.4 \times 10^{5}$ & 0 & $1.0 \times 10^{2}$ & 0 & $1.8 \times 10^{4}$ \\
\hline & Core & $2.8 \times 10^{6}$ & $8.8 \times 10^{5}$ & 0 & $1.0 \times 10^{3}$ & 0 & $1.1 \times 10^{3}$ \\
\hline \multirow{2}{*}{ S2 } & Surface & $6.0 \times 10^{8}$ & $7.0 \times 10^{3}$ & $1.0 \times 10^{2}$ & $2.5 \times 10^{2}$ & $8.2 \times 10^{4}$ & $1.1 \times 10^{4}$ \\
\hline & Core & $4.8 \times 10^{5}$ & $1.9 \times 10^{3}$ & 0 & 0 & 0 & 0 \\
\hline \multirow{2}{*}{ S3 } & Surface & $2.5 \times 10^{8}$ & $1.6 \times 10^{5}$ & 0 & 0 & $7.9 \times 10^{3}$ & $1.2 \times 10^{5}$ \\
\hline & Core & $2.2 \times 10^{8}$ & $2.2 \times 10^{3}$ & 0 & 0 & 0 & $1.7 \times 10^{4}$ \\
\hline \multirow{2}{*}{ S4 } & Surface & $2.9 \times 10^{9}$ & $1.7 \times 10^{5}$ & 0 & 0 & $3.1 \times 10^{4}$ & $3.3 \times 10^{5}$ \\
\hline & Core & $1.2 \times 10^{8}$ & $9.6 \times 10^{4}$ & 0 & 0 & 0 & 0 \\
\hline \multirow[b]{2}{*}{ S5 } & Surface & $3.5 \times 10^{8}$ & $1.4 \times 10^{5}$ & 0 & 0 & 0 & $1.2 \times 10^{6}$ \\
\hline & Core & $4.1 \times 10^{8}$ & $1.3 \times 10^{3}$ & 0 & 0 & 0 & 0 \\
\hline
\end{tabular}

TVBC $=$ Total viable bacterial count

Vibrio spp., Salmonella spp. and Shigella spp were absent in all samples 
TABLE 2. Antibiotic susceptibility of the isolates

\begin{tabular}{|c|c|c|c|c|c|c|c|c|}
\hline \multirow{2}{*}{$\begin{array}{c}\text { Isolates } \\
\text { Antibiotics }\end{array}$} & \multicolumn{2}{|c|}{$\begin{array}{c}\text { Klebsiella spp } \\
\quad \mathbf{N}=6\end{array}$} & \multicolumn{2}{|c|}{$\begin{array}{l}\text { Pesudomonas spp. } \\
\text { N }=5\end{array}$} & \multicolumn{2}{|c|}{$\begin{array}{c}\text { Staphylococcus spp. } \\
\qquad \mathbf{N}=\mathbf{8}\end{array}$} & \multicolumn{2}{|c|}{$\begin{array}{l}E . \text { coli } \\
\mathbf{N}=\mathbf{3}\end{array}$} \\
\hline & $\mathbf{R}$ & $\mathbf{S}$ & $\mathbf{R}$ & $\mathbf{S}$ & $\mathbf{R}$ & $\mathbf{S}$ & $\mathbf{R}$ & $\mathbf{S}$ \\
\hline AMP $(10 \mu \mathrm{g})$ & $0 \%$ & $100 \%$ & $100 \%$ & $0 \%$ & $100 \%$ & $0 \%$ & $25 \%$ & $75 \%$ \\
\hline CIP $(5 \mu \mathrm{g})$ & $25 \%$ & $75 \%$ & $100 \%$ & $0 \%$ & $25 \%$ & $75 \%$ & $70 \%$ & $30 \%$ \\
\hline KAN $(30 \mu \mathrm{g})$ & $25 \%$ & $75 \%$ & $0 \%$ & $100 \%$ & $100 \%$ & $0 \%$ & $25 \%$ & $75 \%$ \\
\hline CEF (30 $\mu \mathrm{g})$ & $50 \%$ & $50 \%$ & $25 \%$ & $75 \%$ & $75 \%$ & $25 \%$ & ND & ND \\
\hline 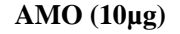 & $50 \%$ & $50 \%$ & $75 \%$ & $25 \%$ & $75 \%$ & $25 \%$ & $50 \%$ & $50 \%$ \\
\hline IPM (30 $\mu \mathrm{g})$ & $0 \%$ & $100 \%$ & $50 \%$ & $50 \%$ & $25 \%$ & $75 \%$ & $25 \%$ & $75 \%$ \\
\hline STR $(10 \mu \mathrm{g})$ & $25 \%$ & $75 \%$ & $0 \%$ & $100 \%$ & $0 \%$ & $100 \%$ & $0 \%$ & $100 \%$ \\
\hline VAN $(30 \mu g)$ & $100 \%$ & $0 \%$ & $100 \%$ & $0 \%$ & $100 \%$ & $0 \%$ & $0 \%$ & $100 \%$ \\
\hline GEN $(10 \mu \mathrm{g})$ & $0 \%$ & $100 \%$ & $0 \%$ & $100 \%$ & $0 \%$ & $100 \%$ & $25 \%$ & $75 \%$ \\
\hline NALI $(30 \mu g)$ & $50 \%$ & $50 \%$ & $0 \%$ & $100 \%$ & $75 \%$ & $25 \%$ & $75 \%$ & $25 \%$ \\
\hline ERY $(15 \boldsymbol{\mu g})$ & $50 \%$ & $50 \%$ & $0 \%$ & $100 \%$ & $75 \%$ & $25 \%$ & $50 \%$ & $50 \%$ \\
\hline
\end{tabular}

$\mathrm{AMP}=$ Ampicillin, $\mathrm{AMO}=$ Amoxicillin, $\mathrm{KAN}=$ Kanamycin, $\mathrm{CIP}=$ Ciprofloxacin, $\mathrm{CEF}=$ Ceftriaxone, NALI= Nalidixic acid, IPM= Imipenem, ERY= Erythromycin, VAN= Vancomycin, GEN= Gentamicin, STR= Streptomycin

Sensitive $=$ S; Registrant $=$ R

TABLE 3. Antibacterial activity of strawberry samples

\begin{tabular}{|c|c|c|c|c|c|c|c|}
\hline \multirow{2}{*}{ Sample } & \multicolumn{7}{|c|}{ Zone of inhibition $(\mathrm{mm})$ against test bacteria } \\
\hline & E. coli & Klebsiella spp. & $\begin{array}{c}\text { Salmonella } \\
\text { spp. }\end{array}$ & Vibrio spp. & Pseudomonas spp. & $\begin{array}{c}\text { Staphylococcus } \\
\text { spp. }\end{array}$ & Listeria spp. \\
\hline Sample 1 & 10 & 22 & 23 & 22 & 25 & 19 & 19 \\
\hline Sample 2 & 12 & 20 & 22 & 19 & 17 & 17 & 18 \\
\hline Sample 3 & 12 & 15 & 14 & 15 & 13 & 13 & 14 \\
\hline Sample 4 & 13 & 14 & 14 & 17 & 15 & 15 & 15 \\
\hline Sample 5 & 15 & 15 & 14 & 16 & 14 & 20 & 15 \\
\hline
\end{tabular}

antibiotics (Kanamycin, Streptomycin, Gentamycin, Nalidixic acid, Erythromycin). The resistance patters have similarity with some previous studies (28).

Resistance of pathogenic bacteria is very critical phenomena in treating diseases caused by them $(29,34-$ 36). This resistance can rapidly transfer to susceptible bacteria making the situation more worse. So it is badly needed to follow the rules and instructions during medical treatment procedures advised or prescribed by physicians.

Many fruits exhibit antimicrobial properties towards different pathogenic bacteria. Many researches have been conducted in this aspect $(28,30-32,34-37)$. Our study continued such work with strawberries to determine antimicrobial activities. After experimentation we have got a good positive result (Table 3). The strawberry samples showed a clear zone of inhibition against seven different kinds of pathogenic bacterial isolates (E. coli, Klebsiella spp., Salmonella spp., Vibrio spp., Pseudomonas spp., Staphylococcus spp. and Listeria spp.). Minimum zone of inhibition was
$10 \mathrm{~mm}$ against $E$. Coli and the maximum zone of inhibition was $25 \mathrm{~mm}$ against Pseudomonas spp. (Table $3)$. The strawberry suspension contains some chemical agents naturally which can inhibit the growth of these bacteria. So strawberries can be used to prepare natural medicinal agents to treat infections caused by these bacteria.

\section{CONCLUSION}

Strawberry as a raw fruit item can cause public health hazards if good agricultural practice, proper handling, appropriate storage conditions are not provided. Because such conditions favor the contamination and rapid multiplication of pathogenic bacteria which after consumption can cause serious health related problems. Nowadays the resistance properties of such bacteria have made the treatment procedures very difficult because they are not killed any more by some antibiotics which were able to inhibit them previously. But our study determined the antibacterial properties from the strawberries which 
can be used as medicinal products to inhibit several bacterial pathogens.

\section{ACKNOWLEDGEMENT}

We are thankful to the authors whose published papers have been cited in this review article. However, there was no financial support or grant for this work.

\section{REFERENCES}

1. Hanning IB, Nutt JD, Ricke SC. 2009. Salmonellosis outbreaks in the United States due to fresh produce: sources and potential intervention measures. Foodborne Pathog. Dis. 6: 635-648.

2. Sivapalasingam S, Friedman CR, Cohen L, Tauxe RV. 2004. Fresh produce: a growing cause of outbreaks of foodborne illness in the united states, 1973 through 1997. J Food Prot. 67: 2342-2353.

3. Anderson M, Jaykus LA, Beaulieu S, Dennis S. 2011. Pathogen-produce pair attribution risk ranking tool to prioritize fresh produce commodity and pathogen combinations for further evaluation (p3arrt). Food Control. 22: 1865-1872.

4. Olaimat AN, Holley RA. 2012. Factors influencing the microbial safety of fresh produce: a review. Food Microbiol. 32: 1-19.

5. Rauha JPS, Remes M, Heinonen A, Hopia M, Kähkönen T, Kujala K, et al. 2000. Antimicrobial effects of finish plant extracts containing flavonoids and other phenolic compounds. Intl. J. Food Microbial. 56: 3-12.

6. Korukluoglu M, Sahan Y, Yigit A. 2008. Antifungal properties of olive leaf extracts and their phenolic compounds. J. Food Safety. 28: 76-87.

7. United States Department of Agriculture. 2007. USDA Database for the Flavonoid Content of Selected Foods. Release 2.1. Available at: http://www.scribd.com/doc/43839695/USDA-Database-for-the FlavonoidContent. Accessed June 3, 2011.

8. Higdon J. 2005. Micronutrient Information Center. Available at: http://lpi.oregonstate.edu/infocenter/phytochemicals/flavonoids/\#intro. Accessed June 5, 2011.

9. Erycesar GY. 2007. Perbandingan efek antibakteri jus stroberi (Fragaria vesca L) pada berbagai konsentrasi terhadap Streptococcus mutans. Bachelor Thesis. Universitas Diponegoro, Semarang.

10. Terry LA, Joyce DC, Adikaram NKB, Khambay BPS. 2004. Preformed antimicrobial compounds in strawberry fruit and flower tissues. Postharvest Biol. Technol. 31: 201-212.

11. Bood KG, Zabetakis I. 2002. The biosynthesis of strawberry flavor (II): Biosynthetic and mo le cu lar b io lo gy studies. J. Food Science. 67: 2-8.

12. Ayala-Zavala JF, Wang SY, Wang CY, GonzálezAguilar GA. 2004. Effect of storage temperatures on antioxidant capacity and aroma compounds strawberry fruit. LWT Food Sci. Technol. 37: 687-695.

13. Harris LJ, Farber JN, Beuchat LR, Parish ME, Suslow TV, Garrett EH, et al. 2003. Outbreaks associated with fresh produce, incidence, growth and survival of pathogens in fresh and fresh-cut produce. Compr. Rev. Food Sci. Food Safety. 2: 78-141.

14. Laidler MR, Tourdjman M, Buser GL, Hostetler T, Repp KK, Leman R, et al. 2013. Escherichia coli O157:H7 infections associated with consumption of locally grown strawberries contaminated by deer. Clin Infect Dis.. 57:1129-1134.

15. Halbwirth H, Puhl I, Haas U, Jezik K, Treutter D, Stich K. 2006. Two phase flavonoid formation in developing strawberry (Fragaria $\times$ ananassa) fruit. J. Agric. Food Chem. 54: 1479-1485.

16. Kosar M, Kafkas E, Paydas SKH. 2004. Baser phenolic composition of strawberry genotypes at different maturation stages. J. Agric. Food Chem. 52: 1586-1589.
17. Nohynek LJ, Alakomi HL, Kähkönen MP, Heinonen M, Helander KM, Oksman-Caldentey KM, et al. 2006. Berry phenolics: Antimicrobial properties and mechanisms of action against severe human pathogens. Nutrition and Cancer. 54:18-32.

18. Puupponen-Pimiä R, Nohynek L, Meier C, Kähkönen M, Heinonen M. 2001. Antimicrobial properties of phenolic compounds from berries. J Appl. Microbiol. 90: 494-507.

19. Puupponen-Pimiä R, Nohynek L, Hartmann-Schmidlin S, Kähkönen M, Heinonen M. 2005. Berry phenolics selectively inhibit the growth of intestinal pathogens. J Appl. Microbiol. 98: 991-1000.

20. Aaby K, Skrede G, Wrolstad RE. 2005. Phenolic composition an antioxidant activities in flesh and achenes of strawberries (Fragaria x ananassa). J. Agric. Food Chem. 53: 4032-4040.

21. Sultana B, Anwar F. 2008. Flavonols (kaempferol, quercetin, myricetin) contents of selected fruits, vegetables and medicinal plants. Food Chem. 108: 879-884.

22. European Food Safety Authority (EFSA). 2014. Scientific opinion on the risk posed by pathogens in food of non-animal origin- Part 2 (Salmonella and Norovirus in berries). EFSA J. 12: 3706.

23. Cappuccino JG, Sherman N. 1996. Microbiology - A laboratory manual The Benjamin/Cummings Publishing Co., Inc., Menlo Park, California.

24. Marjan S, Das KK, Munshi SK, Noor R. 2014. Drug-resistant bacterial pathogens in milk and some milk products. Nutrition \& Food Science. 44 (3): 241-248.

25. Rahman F, Noor R. 2012. Prevalence of pathogenic bacteria in common salad vegetables of Dhaka metropolis. Bangladesh Journal of Botany. 41 (2): 159-162.

26. Hussain A, Wahab S, Zarin I, Hussain MDS. 2010. Antibacterial activity of the leaves of Coccinia indica (W. and A) of India. Adv. Biol. Res. 4 (5): 241 248.

27. Dubey A, Mishra N, Singh N. 2010. Antimicrobial activity of some selected vegetables. Int. J. Appl. Biol. Pharma. Technol. 1 (3): 994-999.

28. Afroz H, Ahmed T, Uddin A. 2015. Microbiological analysis and antibacterial activity of pear samples. Stamford J. Microbiol. 5 (1):1-4.

29. Noor R. 2016. Microbiological quality of commonly consumed street foods in Bangladesh. Nutrition \& Food Science. 46 (1): 130-141.

30. Senjuti JD, Feroz F, Tahera J, Das KK, Noor R. 2014. Assessment of microbiological contamination and the in vitro demonstration of the antibacterial traits of the commonly available local fruit blend within Dhaka Metropolis. Journal of Pharmacognosy and Phytochemistry. 3 (1): 73-77.

31. Fatema N, Acharjee M, Noor R. 2013. Microbiological profiling of imported apples and demonstration of bacterial survival capacity through in vitro challenge test. Ame. J. Microbiol. Res. 1 (4): 98-104.

32. Tahera J, Feroz F, Senjuti JD, Das KK, Noor R. 2014. Demonstration of anti-bacterial activity of commonly available fruit extracts in Dhaka, Bangladesh. American Journal of Microbiological Research. 2 (2): 68-73.

33. Dutta S, Hasan MR, Rahman, F, Jilani MSA, Noor R. 2013. Study of antimicrobial susceptibility of clinically significant microorganisms isolated from selected areas of Dhaka, Bangladesh. Bangladesh Journal of Medical Science. 12 (1): 34-42.

34. Rahman H, Feroz F, Alam MS, Das KK, Rashed Noor. 2016 Demonstration of the source of microbial contamination of freshly cultivated cabbage, cauliflower, potato and squash collected from rural farms of Bangladesh. International Food Research Journal. 23 (3): 1289-1295.

35. Noor R, Malek M, Rahman MS, Meghla M, Acharjee M, Rahman MM. 2015. Assessment of survival of pathogenic bacteria in raw fresh vegetables through in vitro challenge test. International Journal of Food Contamination. DOI: $10.1186 / \mathrm{s} 40550-015-0021-3$

36. Malaviya A, Mishra N. 2011. Antimicrobial activity of tropical fruits. Biological Forum. 3 (1): 1-4.

37. Ahmed T, Urmi NJ, Munna MS, Das KK, Acharjee M, Rahman MM, et al. 2014. Assessment of microbiological proliferation and in vitro demonstration of the antimicrobial activity of the commonly available salad vegetables within Dhaka Metropolis, Bangladesh. American Journal of Agriculture and Forestry. 2 (3): 55-60. 